\title{
Partitioning of respiratory mechanics after cardiac arrest and cardiopulmonary resuscitation
}

\author{
F Ruiz Ferron ${ }^{1 *}$, JM Serrano Simón ${ }^{2}$ \\ From ESICM LIVES 2015 \\ Berlin, Germany. 3-7 October 2015
}

\section{Introduction}

Acute respiratory failure is a frequently complication after cardiac arrest. These patients need mechanical ventilation, however there is a scare information about the components of respiratory mechanics.

\section{Objectives}

To evaluate the total respiratory system mechanics into the lung and chest wall mechanics using the esophageal balloon technique after chest compressions and artificial ventilation post-cardiac arrest.

\section{Methods}

The study was conducted in general intensive care of two tertiary hospitals. 15 patients were studied after hypothermia in clinically stable situation. During volume assist control mechanical ventilation, with constant flow. Esophageal pressure were measured using balloon catheter, positioned by gastric compression procedure. Airways pressure, respiratory flow and esophageal pressure were registered at $100 \mathrm{~Hz}$, and posterior analysis was performed by Ana$\mathrm{dat}^{\circledR}$ software. The passive respiratory mechanics analysis were measured without external PEEP and the other respiratory parameters of mechanical ventilation were unchanged. Multiple linear regression techniques were used to calculate respiratory mechanics and his components, without interruption of mechanical ventilation. Data are expressed as mean \pm standard deviation and range.

\section{Results}

Ventilator parameters were: Vt 0,6 $\pm 0,1, \mathrm{~V}^{\prime} \mathrm{I}: 0,64 \pm$ 0,1L/s, TI:1,0 $\pm 0,3 \mathrm{~s}$, Ttot:2,4 $\pm 0,5 \mathrm{~s}, \mathrm{RR}: 17 \pm 4 \mathrm{bpm}$, Fi02:0,6 \pm 0,2, PEEPe: $0 \mathrm{cmH} 2 \mathrm{O}$. Respiratory system mechanics: Ers $34 \pm 12 \mathrm{cmH} 2 \mathrm{O} / \mathrm{l}$, Rrs $15 \pm 5 \mathrm{cmH} 2 \mathrm{O} / \mathrm{l} / \mathrm{s}$,

${ }^{1}$ Complejo Hospitalario de Jaen, Intensive Care Unit, Jaen, Spain

Full list of author information is available at the end of the article
PEEPi $5 \pm 0.7 \mathrm{cmH} 2 \mathrm{O}$. Chest wall mechanics were, Ecw: $10 \pm 4 \mathrm{cmH} 2 \mathrm{O} / \mathrm{l}$, Rcw:0.7 $\pm 0.4 \mathrm{cmH} 2 \mathrm{O} / \mathrm{l} / \mathrm{s}$. End esophageal espiratory pressure was $15 \pm 5(12-19 \mathrm{cmH} 2 \mathrm{O})$. The mean fraction of Ecw to Ers was $32 \pm 18 \%$ (4 to $82 \%)$.

\section{Conclusions}

Total respiratory system mechanics were abnormal after of chest compressions post-cardiac arrest, a reflection of alteration of lung mechanics. Chest wall compliance showed high variability, similar to other critically ill patients. Higher end espiratory esophageal pressure must be considered in presence of severe respiratory failure.

\section{Authors' details}

${ }^{1}$ Complejo Hospitalario de Jaen, Intensive Care Unit, Jaen, Spain. ${ }^{2}$ Hospital Universitario Reina Sofía, Intensive Care Unit, Córdoba, Spain.

Published: 1 October 2015

\section{doi:10.1186/2197-425X-3-S1-A271}

Cite this article as: Ruiz Ferron and Serrano Simón: Partitioning of respiratory mechanics after cardiac arrest and cardiopulmonary resuscitation. Intensive Care Medicine Experimental 2015 3(Suppl 1):A271.

Submit your manuscript to a SpringerOpen ${ }^{\circ}$ journal and benefit from:

- Convenient online submission

- Rigorous peer review

- Immediate publication on acceptance

- Open access: articles freely available online

- High visibility within the field

- Retaining the copyright to your article

Submit your next manuscript at $\gg$ springeropen.com

\section{SpringerOpen ${ }^{\circ}$}

C 2015 Ruiz Ferron et al.; This is an Open Access article distributed under the terms of the Creative Commons Attribution License (http://creativecommons.org/licenses/by/4.0), which permits unrestricted use, distribution, and reproduction in any medium, provided the original work is properly cited. 